\title{
尿流動態検査における直腸収縮の検討
}

\author{
岡山大学医学部泌尿器科 (主任：大森弘之教授) \\ 小澤 秀夫 永井敦秋山 博伸 \\ 市川 孝治秋山道之進 小野 憲昭 \\ 大枝 忠史 公文 裕巳 大森 弘之

\section{SIGNIFICANCE OF RECTAL CONTRACTIONS DURING MULTICHANNEL URODYNAMIC STUDY}

\author{
Hideo Ozawa, Atsushi Nagai, Hironobu Akiyama, Takaharu Ichikawa, \\ Michinoshin Akiyama, Noriaki Ono, Tadashi Oeda, \\ Hiromi Kumon and Hiroyuki Ohmori \\ Department of Urology, Okayama University Medical School \\ (Director: Prof. Hiroyuki Ohmori)
}

(Background) The influence of rectal contractions on urination was examined using multichannel urodynamic study.

(Methods) We reviewed a total of 246 consecutive urodynamic studies. Each study consisted of a uroflow measurement and multi-channel urodynamic study, evaluating total vesical pressure, abdominal (rectal) pressure, subtracted detrusor pressure and perianal electromyography. Rectal contractions were defined as periodic fluctuations over $5 \mathrm{cmH}_{2} \mathrm{O}$ in abdominal pressure detected by a rectal balloon catheter. No relationship of these contractions with cough and breathing was observed.

(Results) Of the 246 patients, 17 (6.9\%) had a positive study for rectal contractions. The patients, who had positive rectal contractions, averaged 70 -year-old were older than negative subjects averaged 62-year-old. In multichannel urodynamics, the flow rate was significantly decreased, and electromyographic activity was increased at the moment of each rectal contractions.

(Conclusion) The rectal contractions are not artifactual and may be regarded as one of causes responsible for urinary difficulty in the elderly.

Key words: rectal contractions, multi-channel urodynamic study, difficulty of urination

要旨：(背景と目的）我々は，直腸収縮が尿流率と括約筋電位に与える影響を検討した.

（対象と方法）対象は直腸内圧測定を含む Pressure-flow study 併用尿流動態検査を施行した246名で ある．尿流測定と残尿測定を施行後，膀胱内圧，直腸内圧，尿流測定，括約筋筋電図を同時測定する尿 流動態検査を日常排尿と同じ姿勢で施行した。咳嗽，呼吸と関係の無い $5 \mathrm{cmH}_{2} \mathrm{O}$ 以上の周期的な直腸内 圧の上昇（以下直腸収縮と略す）を直腸収縮として検討した.

（結果）直腸収縮を認めた症例は17名（6.9\%）であった，直腸収縮陽性群の年齢は70歳，直腸収縮陰 性群は62歳であり直腸収縮は高齢者において頻度が高かった. Pressure-flow study では直腸収縮直前の 尿流率と直腸収縮時の尿流率を比較すると直腸収縮時の尿流率は低下しており，括約筋筋電図では直腸 収縮時に電位が上昇する傾向を認めた。

（結論）直腸収縮は，高齢者の排尿障害の一因である可能性が示唆された。 キーワード：直腸収縮, 尿流動態検査, 排尿障害 


\section{緒言}

尿流動態検查施行時に, 膀胱内圧とともに直腸内圧 を計測し排尿筋圧を求める方法は Blaivas ${ }^{1)}$ の報告以 来,一般的なものとなってきている. 我々の施設でも, 原則として直腸内圧測定を併用して尿流動態検査を施 行している.

この直腸内圧測定併用下の尿流動態検査において, 直腸内圧が周期的に変動する症例を少なからず経験し ている.しかし，尿流動態検查における直腸内圧に関 する報告の多くは腹圧に関するものであり ${ }^{21 \sim 5)}$, 排尿 にともなう圧変動とは無関係に存在する直腸内圧固有 の変動についての報告はほとんどない ${ }^{6)}$.

今回我々は, Pressure-flow study を含む尿流動態検 查における直腸内圧の周期的な変動(以下，直腸収縮） が，膀胱内圧，尿流率と括約筋筋電図に与える影響を 検討したので報告する。

\section{対象および方法}

対象は, 平成 4 年 4 月より平成 7 年 3 月までの期間, 岡山大学泌尿器科で直腸内圧測定を含む尿流動態検査 を施行した246名である。

通常の尿流測定を施行した後, 尿流動態検査を日常 の排尿と同じ体位（男性立位，女性座位）で施行した。 測定機械はUrodyn 5500 Urocolor videosystem (Dantec ${ }^{\mathrm{TM}}$ ) を使用し, 膀胱内圧は経尿道的に生理食塩 水を充満させた 8 Fr 2WAY CMG catheter $\left(\mathrm{Cliny}^{\mathrm{TM}}\right)$ で, 直腸内圧は rectal balloon (三興化学 ${ }^{\mathrm{TM}}$ ) に Manometer connecting tube (200/485/150: Portex $^{\mathrm{TM}}$ ) を接続し, Manometer (P23XL : Statham ${ }^{\mathrm{TM}}$ ) で piezometric pressure head を記録した。筋電図は 肛門周囲表面電極 (13L42：Dantec ${ }^{\mathrm{TM}}$ ) で検討した．注 入媒体は低濃度造影剤 $(30 \%$ Iothalamate meglumine あるいは Iopamidol 150）を使用し，50ml/分の速さで 膀胱内に注入した.

直腸収縮の定義は, 咳嗽, 呼吸と関係の無い $5 \mathrm{cmH}_{2} \mathrm{O}$
以上の周期的な直腸内圧の上昇 ${ }^{6}$ とし，直腸内圧上昇 と膀胱内圧，尿流率，筋電図との関連性を検討した。 なお，直腸収縮を判定する時は， $5 \mathrm{cmH}_{2} \mathrm{O}$ 前後の圧 変動が判定しやすいように，圧曲線のスケールは，一 目盛 $10 \mathrm{cmH}_{2} \mathrm{O}$ (当施設の尿流動態検査では通常の症例 では一目盛 $30 \mathrm{cmH}_{2} \mathrm{O}$ を採用）と細かく設定して検討 した.

また, 測定方法および各種名称は International continence society の基準》に従い，有意差検定にはカイ 2 乗検定と Wilcoxon 検定を使用した.

\section{結果}

1）直腸収縮陽性率

直腸収縮は246名中17名（6.9\%）に陽性であった。 男性は128名中11名 $(8.6 \%)$, 女性は118名中 6 名 （5.1\%）で陽性であり，明らかな性差は認めなかった (表 1 ).

直腸収縮陽性群の疾患別内訳を表 2 に示したが, 神 経疾患を合併していない症例（前立腺肥大症 2 名，そ の他 7 名）にも直腸収縮は認められ全体の53\% (9/17) を占めていた（表 2 ).

年齢別頻度では，50歳以降で直腸収縮の陽性率が上 昇する傾向を認めた (図 1 )。直腸収縮陽性症例の年齢 は70 13 歳（mean \pm s.d.）であったが，直腸収縮陰性 症例の年齢は $62 \pm 17$ 歳と, 直腸収縮は高齢者に多く認 められた。

2) 症例

代表的な症例を提示する（図 2 ）.

表 1 直腸収縮の頻度

\begin{tabular}{|c|c|c|c|}
\hline & 直腸収縮陽性 & 直腸収縮陰性 & 計 \\
\hline 男 性 & $11(8.6 \%)$ & $117(91.4 \%)$ & $128(100 \%)$ \\
\hline \multirow[t]{2}{*}{ 女 性 } & $6(5.1 \%)$ & $112(94.9 \%)$ & $118(100 \%)$ \\
\hline & $17(6.9 \%)$ & $229(93.1 \%)$ & $246(100 \%)$ \\
\hline
\end{tabular}

表 2 直腸収縮陽性症例の疾患別頻度

\begin{tabular}{|c|c|c|}
\hline 疾 患 & 直腸収縮陽性 & 直腸収縮陰性 \\
\hline $\begin{array}{l}\text { 脳疾患 } \\
\text { 脊䯣疾患 } \\
\text { 未梢神経疾患 } \\
\text { 混合疾患 } \\
\text { 前立腺肥大症 } \\
\text { その他 }\end{array}$ & $\begin{array}{l}2 \text { 名 }(11.8 \%) \\
0 \text { 名 }(0.0 \%) \\
5 \text { 名 }(29.4 \%) \\
\text { 1名 }(5.9 \%) \\
2 \text { 名 }(11.8 \%) \\
7 \text { 名 }(41.2 \%)](53.0 \%)\end{array}$ & $\begin{array}{l}37 \text { 名 }(16.1 \%) \\
32 \text { 名 }(14.0 \%) \\
64 \text { 名 }(28.0 \%) \\
10 \text { 名 }(4.4 \%) \\
25 \text { 名 }(10.9 \%) \\
61 \text { 名 }(26.6 \%)-(37.5 \%)\end{array}$ \\
\hline 計 & 17 名 $(100 \%)$ & 229 名 $(100 \%)$ \\
\hline
\end{tabular}


図 1 直腸収縮陽性症例の年齢別頻度

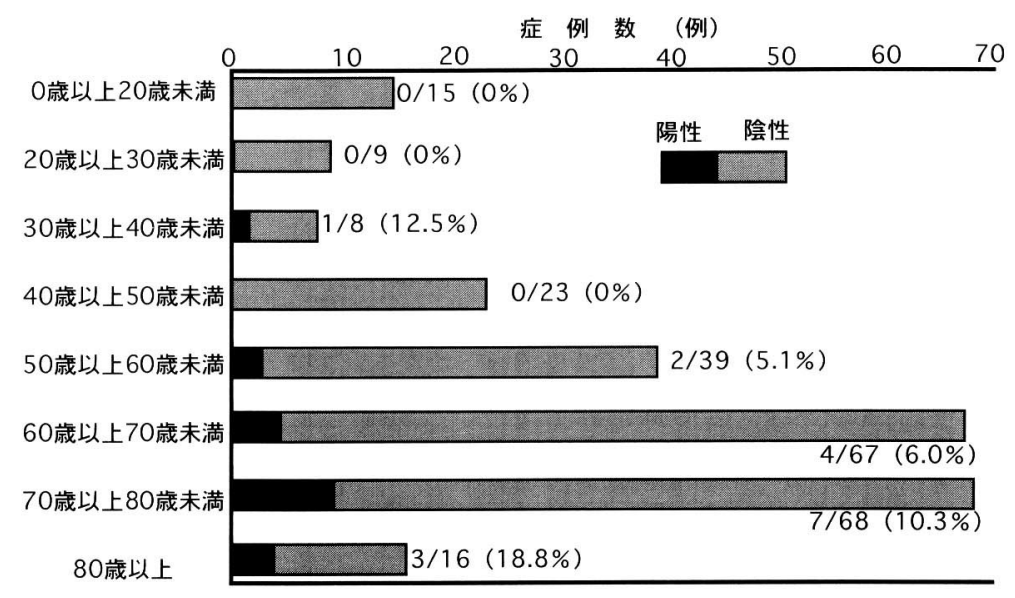

図 2 症例

75歳, 男性.

主訴：頻尿, 排尿困難.

既往歴：前立腺肥大症.

蓄尿期：過活動排尿筋活動, 直腸収縮陽性.

排尿期：正常排尿筋収縮力, 直腸収縮陽性.

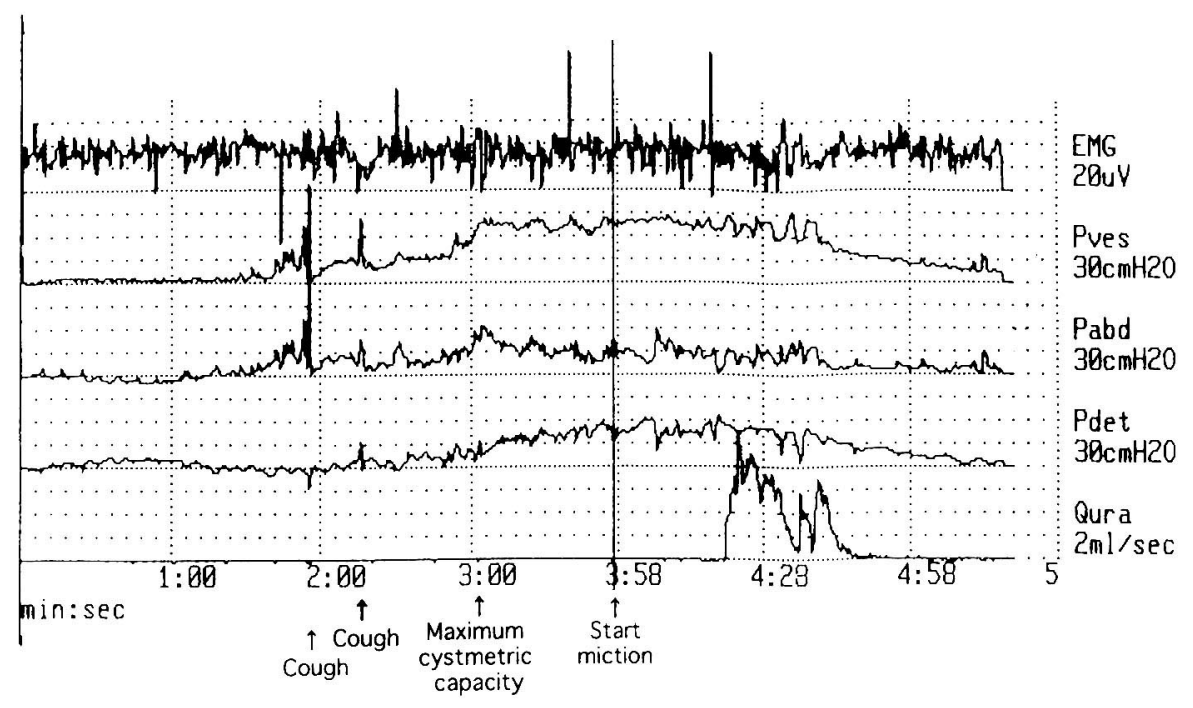

75歳男性, 主訴は頻尿, 排尿困難である. 軽度の前 立腺肥大症以外に排尿障害の原因となる基礎疾患を認 めない。

蓄尿時に, 直腸内圧が周期的に変動したが, 膀胱内 压の周期的変動はなかった. $125 \mathrm{ml}$ 注入後より排尿筋 圧が上昇し過活動排尿筋機能の所見であった。括約筋 電位は直腸収縮とほほ同期して変動した。

排尿時においても，直腸収縮は持続しており，尿流
波形は鋸歯状を示した。

3）直腸収縮の尿流に与える影響

次に, pressure-flow study において，直腸收縮の排 尿に与える影響を検討寸るため, 直腸収縮前の尿流率 と直腸収縮における直腸内压ピーク時の尿流率を比較 し尿流率の低下率（\%）を個々の症例で検討した。解 析は直腸収縮の認められた18例のうち, 尿流動態検查 時に直腸収縮前の尿流率が $2 \mathrm{ml} / \mathrm{sec}$ 以上となる排尿の 
図 3 直腸収縮時尿流低下率の解析方法

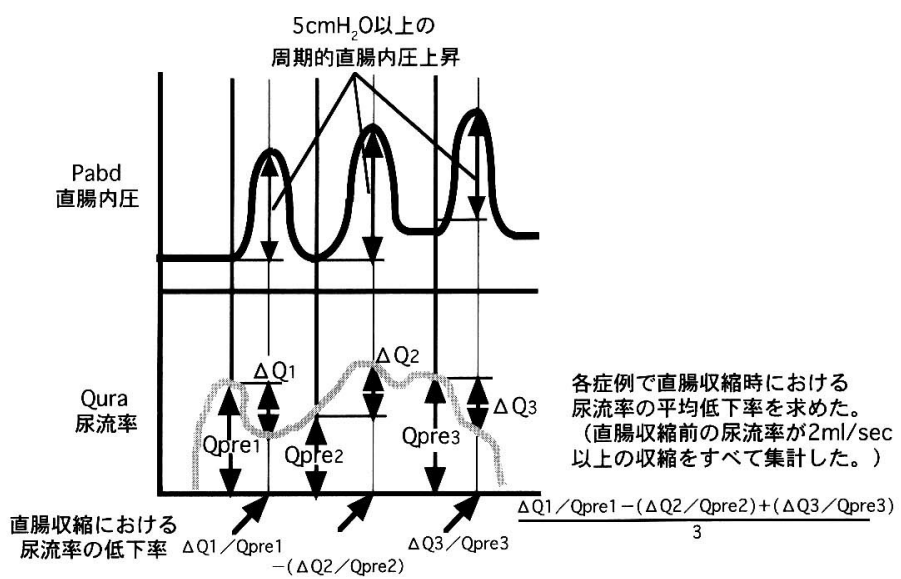

図 4 呈示症例における直腸収縮時尿流低下率

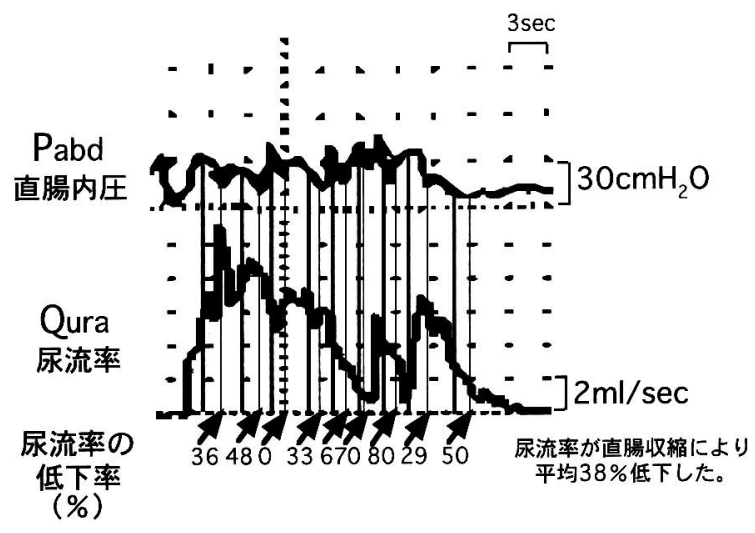

得られた13例を対象とした。

直腸収縮時に尿流率が低下した収縮はプラスで, 直 腸収縮時に尿流率が逆に上昇した収縮はマイナスで, 各収縮における尿流低下率を各個の症例における平均 值で求めた。な抢, 直腸収縮前の尿流率が $2 \mathrm{ml} / \mathrm{sec}$ 以下 の直腸収縮は, 誤差が大きく尿流低下率が正確に算定 できない可能性があるので, 検討から除外した(図 3 ). 前述の症例における尿流低下率の解析を例示する と, 直腸収縮時に尿流率が平均 $38 \%$ 低下した（図 4 ）。 その結果, $2 \mathrm{ml} / \mathrm{sec}$ 以上の尿流率で直腸収縮を生じた 13例において, 直腸収縮時に尿流率は平均 $9.1 \%$ の低下 が認められた（表 3 )。

\section{考 察}

直腸収縮は，正常人にも認められることが知られて いる. Kumar ( $^{8199}$ は, 17歳から55歳の健常成人 12 名に
直腸内圧測定を連続で平均 20 時間施行した.その結果, 生理的な直腸収縮は睡眠時あるいは食後に頻度が高 く，これらの生理的な直腸収縮は大きく分けて下記の 3 種類であると述べている.

1） 1 分間 $2 \sim 3$ 回の強力な収縮が $3 \sim 10$ 分持続す るもの.

2）覚醒時に多い10２0秒間持続する独立した収縮.

3）食後に多い 1 分間 $5 \sim 6$ 回 $1 \sim 2$ 分程度持続す る収縮。

今回検討の対象とした直腸収縮は，1 分間に10回前 後の頻度で蓄尿時から排尿時にかけて少なくとも尿流 動態検査の間（5 分間以上）持続していた。つまり, 収縮の頻度, 性質より考えて生理的な直腸収縮とは本 質的に異なるものと思われる. また, 我々の検討で神 経学的に排尿異常の原因となる疾患が存在しない症例 にも比較的高頻度に認められ，30歳末満の患者には皆 無であったことより，検査用直腸バルーンの刺激によ る生理的排便反射とも無関係であると思われた.

排尿前後に観測される直腸内圧の上昇に関する報 告 ${ }^{2) ~ 5)}$ は多いが, これは周期的な現象ではなく, 排尿を 企図する前後にイベント的に直腸内压が上昇するも の, すなわち, 腹圧排尿の際に認められる直腸内圧の 変動に関する報告である。

排尿に伴う腹圧上昇とここでいう直腸収縮の違い は, 前者が排尿に伴って変動するのに対し, 後者は排 尿と直接的には無関係である点である，その鑑別は蓄 尿時には容易であるが，排尿時には鑑別困難な場合も 存在する。したがって, 今回の検討では蓄尿時から排 尿時にかけて認められる周期的な直腸内圧上昇で，か 
表 3 直腸収縮陽性症例と尿流率の低下率

\begin{tabular}{|c|c|c|c|c|}
\hline 症例 & 年齢/性別 & 疾 患 名 & 既 往 歴 & $\begin{array}{c}\text { 直腸収縮に伴う } \\
\text { 流率の減少率 } \\
(\%)\end{array}$ \\
\hline 1 & $30 / \mathrm{M}$ & 特になし & 右尿管結石 & -* \\
\hline 2 & $53 / \mathrm{M}$ & 特になし & 膀胱腫瘍 & 19 \\
\hline 3 & $57 / \mathrm{M}$ & 特になし & 肺結核 & 17 \\
\hline 4 & $61 / \mathrm{F}$ & パーキンソン病 & 特になし & 0 \\
\hline 5 & $65 / \mathrm{F}$ & 特になし & 特になし & 17 \\
\hline 6 & $68 / \mathrm{M}$ & 前立腺肥大症 & 特になし & -35 \\
\hline 7 & $68 / \mathrm{M}$ & 橋前部腫瘍 & 特になし & 8 \\
\hline 8 & $70 / \mathrm{F}$ & 脳性麻痺 & 特になし & $-^{*}$ \\
\hline 9 & $70 / \mathrm{M}$ & 特になし & 前立腺肥大症術後 & 19 \\
\hline 10 & $75 / \mathrm{M}$ & 前立腺肥大症 & 特になし & 38 \\
\hline 11 & $77 / \mathrm{F}$ & 子宮癌術後 & 特になし & -39 \\
\hline 12 & $78 / \mathrm{M}$ & 糖尿病 & 特になし & - $^{*}$ \\
\hline 13 & $78 / \mathrm{M}$ & 椎間板ヘルニア (L3-4) & 特になし & 39 \\
\hline 14 & $79 / \mathrm{F}$ & 糖尿病 & 特になし & 13 \\
\hline 15 & $84 / \mathrm{M}$ & 特になし & 前立腺肥大症術後 & - $^{*}$ \\
\hline 16 & $85 / \mathrm{F}$ & 子宮癌術後 & 特になし & 13 \\
\hline 17 & $85 / \mathrm{M}$ & 特になし & 心不全 & - $^{*}$ \\
\hline
\end{tabular}

*: Pressure-flow study の時に, 排尿が得られなかったか, 直腸収縮前の尿流率が2 $\mathrm{ml} / \mathrm{sec}$ 以上とならなかったため尿流率の減少率が算出できなかった症例

つ，排尿に伴う腹圧上昇と鑑別可能なものを直腸収縮

として解秎した。

今回の検討で，尿流率を直腸収縮前と直腸収縮時と で比較したが，直腸収縮時に尿流率が明らかに低下し ていた．排尿中は排尿に伴う腹圧上昇と固有の直腸収 縮による腹圧上昇は頻似している場合も認められる。 しかし，直腸収縮による圧上昇は周期が短く，排尿に 伴う腹圧上昇は比較的大きな圧変動を示すことで区別 することができる，従って，腹圧上昇と直腸収縮によ る圧上昇を混同する可能性は少なく, 直腸収縮が尿流 率に影響を与えていることは明らかであると思われ た.

また計測にあたっては，直腸内圧測定と尿流率曲線 の時間差も考慮に入れるのが望ましい.Kranse ら ${ }^{10} に$ よると, 膀胱内圧の変動が尿流曲線に反映される時間 差は女性で平均 0.4 秒, 男性で平均 0.6 秒と報告されて いる. 我々の施設において，膀胱内圧と直腸内圧は Kranse と同じ液体充満法で計測しているために同程 度のずれが予想されるが，排尿時の表示測定最小限界 值である0.5秒と同程度に短い時間であるので, 時間差 による補正は特に行わなかった。

また，症例で認められたように筋電図の電位が直腸 収縮時に上昇する傾向を多くの直腸収縮陽性症例で認 めた。我々は，肛門周囲表面電極を用いて筋電図を記
録しており，定量的な尿道括約筋の評価は不可能であ る.しかし, 肛門周囲表面電極による筋電図は, 全体 として骨盤底の筋緊張状態を推測しうる ${ }^{7111}$ 。すなわ ち, 直腸収縮時に尿流が低下するのは, 同時に骨盤底 の筋緊張が高まり尿道を閉鎖するよう作用しているこ とが示唆された。

また，直腸収縮による尿流率低下時に排尿筋圧の上 昇は伴わなかった。排尿筋圧は膀胱内圧より直腸内圧 を subtract したものであるという定義1)より, 直腸収 縮に伴う膀胱内圧の上昇が直腸内圧の上昇をこえるこ とはないからであろう.すなわち, 尿流率の低下を腹 压の上昇でおぎなうための直腸内圧が上昇するのでは なく, 直腸内圧の上昇が尿流率の低下に先立って起こ るものと思われた。

排尿時に尿道括約筋あるいは尿道周囲の筋緊張が高 まり排尿が障害される病態として排尿筋括約筋協調不 全 (detrusor-sphincter-dyssynergia：以下 DSD) が知 られている. 直腸収縮では, 排尿時, 尿流動態検査で 認められる所見はまさにDSDのそれである ${ }^{122}$.すな わち, 直腸収縮は, 排尿時のみでなく蓄尿時にも持続 するDSD の特殊な一型である可能性も考えられる。

直腸収縮の頻度については, Combs ら ${ }^{6}$ が $38 \%$ と報 告しており, 我々の $6.9 \%$ よ高值である.これは, Combs らはrhythmic な収縮も randomな収縮もと 
もに検討の対象としたが，我々は周期的な（rhythmic な）収縮のみを検討したことによる差であると思われ る、いずれにしても，尿流動態検査において直腸収縮 は，ある程度の頻度で認められるものと思われる。

また，直腸収縮の病因は不明であるが，高齢者に高 頻度であったことより，老化による排尿障害との関連 性が示唆される。

従来は高齢男性の下部尿路閉塞性症状をすべて前立 腺症として一括してきたが，近年の研究により，前立 腺症と呼ぶには問題が少なくない多様な病態を包括し ていることが明らかとなってきた ${ }^{13)}$. 直腸収縮はこう した下部尿路閉塞性症状のうち, 前立腺症とは無関係 におこりうる機能的な閉塞の一因である可能性が高 い.

今後, 症例を追加して検討するとともに，病因や治 療法についても検討しなくてはならないと考えてい る.

\section{結 語}

1. 直腸収縮はマルチチャンネル尿流動態検査施行 症例の $6.9 \%$ に認められた。

2. 高齢者に高頻度であった。

3. 直腸収縮時, 尿流率は低下し, 肛門周囲表面電極 による筋電図における電位は上昇する傾向を認めた。

4. 排尿筋括約筋協調不全の一型である可能性が示 唆された。

本論文の要旨は第 2 回神経因性膀胱学会にて発表した. 文 献

1) Blaivas, J.: Multichannel urodynamics. Urology, 23, 421-438, 1984.

2) Jensen, K.M.E., Bruskewitz, R.C., Iversen, P. and Madsen, P.O.: Abdominal straining in benign hyperplasia. J. Urol., 129, 44-47, 1983.

3) Meffan, P.J., Nacey, J.N. and Delahunt, B.: Effect of abdominal straining on urinary flow rate in normal male. Brit. J. Urol., 67, 134139, 1991.

4）森田 勝, 岡本正紀, 渡辺紀代隆, 越知憲治, 竹内 正文：腹圧排尿。日泌尿会誌，77，1814-1830，
1986.

5）小澤秀夫，小野憲昭，市川孝治，志田原浩二，大枝 忠史，公文裕巳，大森弘之：Pressure-flow study による腹圧排尿の臨床的検討。排尿障害プラクラ イス, 2, 429-430, 1994.

6) Combs, T.A. and Nitti, V.W.: Significance of rectal contractions noted on multichannel urodynamics. Neurouro. Urodyn., 14, 73-80, 1995.

7) Abrams, P., Blaivas, J.G., Stanton, S.L. and Andersen, J.T.: Standardization of terminology of lower urinary tract function. Neurouro. Urodyn., 7, 403-427, 1988.

8) Kumar, D., Williams, N.S., Waldron, D. and Wingate, D.L.: Prolonged manometric recording of anorectal motor activity in ambulant human subjects : Evidence of periodic activity. Gut, 30, 1007-1011, 1989.

9) Kumar, D., Waldron, D., Williams, N.S., Browning, C., Hutton, M.R.E. and Wingate, D.L.: Prolonged anorectal manometry and external anal sphincter electromyography in ambulant human subjects. Dig. Dis. Sci., 35, 641-648, 1990.

10) Kranse, R., Mastrigt, R.V. and Bosch, R.: Estimation of the lag time between detrusor pressure-and flow rate-signals. Neurourol. Urodyn., 14, 217-229, 1995.

11) Wein, A.J.: Neuromuscular dysfunction of the lower urinary tract. Campbell's Urology. 6th Edit. Philadelphia, Saunders. p589-593, 1992.

12) Scott, F.B., Queseda, E.M. and Cardus, D. : The use of combined uroflowmetry, cystometry and electromyography in evaluating of neurogenic bladder dysfunctions. Neurogenic bladder. William \& Wilkins Company, p106-114, 1967.

13) Abrams, P.: Managing lower urinary tract symptoms in older men. Brit. Med. J., 310, 1113 -1117, 1995. （1995年12月7日受付，1997年4月9日受理） 